\title{
CALIBRATION INTRODUCTION
}

\section{E M Scott}

Department of Statistics, University of Glasgow, University Gardens, Glasgow, G12 8QW, United Kingdom. Email: marian@stats.gla.ac.uk.

\section{P J Reimer}

School of Geography, Archaeology and Palaeoecology, Queen's University Belfast, Elmwood Avenue, Belfast BT7 1NN, United Kingdom. Email: p.j.reimer@qub.ac.uk.

There are 2 fundamental assumptions in radiocarbon dating, which were known early in the method development to be approximations, and which lead directly to the need to calibrate ${ }^{14} \mathrm{C}$ dates:

1. The rate of formation of ${ }^{14} \mathrm{C}$ in the upper atmosphere has been constant over the entire applied ${ }^{14} \mathrm{C}$ dating timescale (approximately the last 65,000 yr).

2. The ${ }^{14} \mathrm{C}$ activity of the atmosphere has been in equilibrium with the biosphere and ocean over the applied timescale.

Perhaps the most fundamental assumption is that the relative isotopic abundance of carbon atoms in a particular reservoir (e.g. the atmosphere) has remained constant. Even in the early days, this assumption was challenged by discrepancies reported between the measured ${ }^{14} \mathrm{C}$ ages and the known calendar dates (dendro-dates) of relatively modern wood samples (de Vries 1959) and further evidence continued to accumulate. The most comprehensive evidence of these variations was due to the considerable effort of some of the giants of ${ }^{14} \mathrm{C}$ dating, who made direct measurements of ${ }^{14} \mathrm{C}$ concentrations in tree rings (Suess 1965; Stuiver and Suess 1966; Damon 1982; Pearson and Baillie 1983). The explanations for the observed variations were both short- and long-term variations in the ${ }^{14} \mathrm{C}$ production rate due to solar sunspot activity and geomagnetic modulation. It then followed naturally that variations in production rate will influence the ${ }^{14} \mathrm{C}$ activity of the atmosphere and hence the biosphere and ocean. Changes in ocean circulation and carbon storage were also implicated in altering the ${ }^{14} \mathrm{C}$ activity of the atmosphere (Stuiver et al. 1991; Denton and Hendy 1994; Broecker 1997). For example, the rate of formation of deep water in the North Atlantic has been postulated to have significantly decreased during the Younger Dryas, resulting in a buildup of ${ }^{14} \mathrm{C}$ in the atmosphere (Fairbanks 1989; Bard et al. 1990; Edwards et al. 1993).

In addition to these entirely natural variations, since the late 19th century there have been 2 known anthropogenic effects resulting in variations in the atmosphere. The first is due to the combustion of fossil fuels (the Industrial or Suess effect; diluting the ${ }^{14} \mathrm{C}$ activity) and the second, nuclear weapons testing (the Bomb or Nuclear effect; enhancing the ${ }^{14} \mathrm{C}$ activity).

All might then seem lost in this variation, yet ${ }^{14} \mathrm{C}$ dating as an applied technique has flourished through the development of calibration tools and through detailed study of the fluctuations of ${ }^{14} \mathrm{C}$. Indeed, the fluctuations themselves are of considerable interest to geophysicists and climate scientists.

Calibration of ${ }^{14} \mathrm{C}$ measurements requires knowledge of the levels of atmospheric ${ }^{14} \mathrm{C}$ in the past. This has come from ${ }^{14} \mathrm{C}$ measurements made on long series of known-age material, including tree rings, corals, and varved sediments of marine origin, etc., and the evidence continues to expand. The bulk of the evidence, from the archive with the longest history of study, has been from dendrochronologically dated trees. For many years, this archive was the only basis of the calibration tables and

(C) 2009 by the Arizona Board of Regents on behalf of the University of Arizona Celebrating 50 Years of Radiocarbon

RADIOCARBON, Vol 51, Nr 1, 2009, p 283-285 
curves where the ${ }^{14} \mathrm{C}$ age of the tree rings was listed or plotted against the absolute age (normally in decadal or bidecadal spans). Progressively since the 1980s, results have been added to the dendrobased calibration curve, extending the timescale and improving the precision (including single-ring results). But, as the availability of dendro-dated tree rings has become more and more limited in the timescales of interest, researchers have moved to other archives, including corals and varved marine sediments, extending the timescale back further (Stuiver et al. 1998). A number of special issues of the journal Radiocarbon (Volumes 28, 35, 40, and 46) have provided a compendium (and best knowledge at the time) of the calibration data. The most recent of these included the IntCal04 and Marine04 curves (Hughen et al. 2004; Reimer et al. 2004), which extended to $26 \mathrm{kyr}$ BP using a new approach to calibration curve construction that accounted for the uncertainty in both the ${ }^{14} \mathrm{C}$ and calendar ages (Buck and Blackwell 2004). Since that time, a number of data sets have been used to provide calendar age estimates beyond $26 \mathrm{kyr} \mathrm{BP}$, but there is not yet a ratified calibration curve available (Fairbanks et al. 2005; Hughen et al. 2006). The IntCal Working Group continues to work on the development of a ratified update, although there remain some issues concerning the applicability of many of the available archives for providing calibration data relevant for marine and terrestrial calibration (van der Plicht et al. 2004).

As the available data for calibration increased in volume and improved in quality, there have been significant changes to the actual calibration method being used, moving from the very simple curve intersection approach to the much more complex probabilistic approach (often Bayesian). At the same time, there have been major developments in the calibration software. Nowadays, there are a number of calibration programs available for terrestrial samples; the most widely used being CALIB, BCal, and OxCal, which are easily downloadable from the web or run on-line, as well as a number of special purpose programs such as BPeat, BChron, and CaliBomb.

Calibration remains an important practical and scientific issue, even though from those early days, the failure of the key assumptions might have seemed likely to doom the dating method to oblivion. Major challenges remain in pushing back the time limits over which we are able to calibrate and in applying the results to marine samples. Our need to calibrate our ${ }^{14} \mathrm{C}$ dates comes from the fluctuations in the ${ }^{14} \mathrm{C}$ levels in the atmosphere, but that too now is seen as a feature of scientific relevance and importance in its own right. We learn about our Sun and geomagnetic field modulation; we have the opportunity to study the interactions between the main carbon reservoirs (using ${ }^{14} \mathrm{C}$ as a natural tracer) have a chronometer used in many areas of science.

\section{REFERENCES}

Bard E, Hamelin B, Fairbanks RG. 1990. U-Th ages obtained by mass spectrometry in corals from Barbados: sea level during the past 130,000 years. Nature 346(6283):456-8.

Broecker WS. 1997. Thermohaline circulation, the Achilles heel of our climate system: Will man-made $\mathrm{CO}_{2}$ upset the current balance? Science 278(5343):1582-8.

Buck CE, Blackwell PG. 2004. Formal statistical models for estimating radiocarbon calibration curves. Radiocarbon 46(3):1093-102.

Damon PE. 1982. Fluctuation of atmospheric radiocarbon and the radiocarbon time scale. ACS Symposium Series 176:233-44.

Denton GH, Hendy CH. 1994. Younger Dryas age advance of Franz Josef Glacier in the Southern Alps of New Zealand. Science 264(5164):1434-7. de Vries H. 1959. Measurement and use of natural radiocarbon. In: Abelson PH, editor. Researches in Geochemistry. New York: John Wiley \& Sons. p 169-89.

Edwards RL, Beck JW, Burr GS, Donahue DJ, Chappell JMA, Bloom AL, Druffel ERM, Taylor FW. 1993. A large drop in atmospheric ${ }^{14} \mathrm{C} /{ }^{12} \mathrm{C}$ and reduced melting in the Younger Dryas, documented with ${ }^{230} \mathrm{Th}$ ages of corals. Science 260(5110):962-8.

Fairbanks RG. 1989. A 17,000-year glacio-eustatic sea level record: influence of glacial melting rates on the Younger Dryas event and deep-ocean circulation. $\mathrm{Na}$ ture 342(6250):637-42.

Fairbanks RG, Mortlock RA, Chiu T-C, Cao L, Kaplan A, Guilderson TP, Fairbanks TW, Bloom AL, Grootes PM, Nadeau M-J. 2005. Radiocarbon calibration curve spanning 0 to 50,000 years BP based on paired 
${ }^{230} \mathrm{Th} /{ }^{234} \mathrm{U} /{ }^{238} \mathrm{U}$ and ${ }^{14} \mathrm{C}$ dates on pristine corals. Quaternary Science Reviews 24(16-17):1781-96.

Hughen KA, Baillie MGL, Bard E, Beck JW, Bertrand CJH, Blackwell PG, Buck CE, Burr GS, Cutler KB, Damon PE, Edwards RL, Fairbanks RG, Friedrich M, Guilderson TP, Kromer B, McCormac G, Manning S, Bronk Ramsey C, Reimer PJ, Reimer RW, Remmele S, Southon JR, Stuiver M, Talamo S, Taylor FW, van der Plicht J, Weyhenmeyer CE. 2004. Marine04 marine radiocarbon age calibration, $0-26 \mathrm{cal} \mathrm{kyr} \mathrm{BP.} \mathrm{Ra-}$ diocarbon 46(3):1059-86.

Hughen K, Southon J, Lehman S, Bertrand C, Turnbull J. 2006. Marine-derived ${ }^{14} \mathrm{C}$ calibration and activity record for the past 50,000 years updated from the Cariaco Basin. Quaternary Science Reviews 25(23-24): 3216-27.

Pearson GW, Baillie MGL. 1983. High-precision ${ }^{14} \mathrm{C}$ measurement of Irish oaks to show the natural atmospheric ${ }^{14} \mathrm{C}$ variations of the $\mathrm{AD}$ time period. Radiocarbon 25(2):187-96.

Reimer PJ, Baillie MGL, Bard E, Bayliss A, Beck JW, Bertrand CJH, Blackwell PG, Buck CE, Burr GS, Cutler KB, Damon PE, Edwards RL, Fairbanks RG, Friedrich M, Guilderson TP, Hogg AG, Hughen KA, Kromer B, McCormac G, Manning S, Bronk Ramsey
C, Reimer RW, Remmele S, Southon JR, Stuiver M, Talamo S, Taylor FW, van der Plicht J, Weyhenmeyer CE. 2004. IntCal04 terrestrial radiocarbon age calibration, 0-26 cal kyr BP. Radiocarbon 46(3):1029-58.

Stuiver M, Suess HE. 1966. On the relationship between radiocarbon dates and true sample ages. Radiocarbon 8:534-40.

Stuiver M, Braziunas TF, Becker B, Kromer B. 1991. Climatic, solar, oceanic, and geomagnetic influences on late-glacial and Holocene atmospheric ${ }^{14} \mathrm{C} /{ }^{12} \mathrm{C}$ change. Quaternary Research 35(1):1-24.

Stuiver M, Reimer PJ, Braziunas TF. 1998. High-precision radiocarbon age calibration for terrestrial and marine samples. Radiocarbon 40(3):1127-51.

Suess HE. 1965. Secular variations of the cosmic-rayproduced carbon 14 in the atmosphere and their interpretations. Journal of Geophysical Research 70(23): 5937-52.

van der Plicht J, Beck JW, Bard E, Baillie MGL, Blackwell PG, Buck CE, Friedrich M, Guilderson TP, Hughen KA, Kromer B, McCormac FG, Bronk Ramsey C, Reimer PJ, Reimer RW, Remmele S, Richards DA, Southon JR, Stuiver M, Weyhenmeyer CE. 2004. NotCal04-comparison/calibration ${ }^{14} \mathrm{C}$ records $26-$ 50 cal kyr BP. Radiocarbon 46(3):1225-38. 